\title{
First Record of Brachiopods from the Marquesas Islands, French Polynesia, South Central Pacific ${ }^{1}$
}

\author{
Maria Aleksandra Bitner ${ }^{2}$
}

\begin{abstract}
Two species of Recent brachiopods, Eucalathis cf. murrayi and Frenulina sanguinolenta, have been identified in the collection from the Musorstom 9 Expedition to the Marquesas Islands in 1997. They represent the first record of brachiopods from the Marquesas Islands. Both species previously have been reported from the western Pacific, and F. sanguinolenta is also known from Hawai'i in the North Central Pacific. Presence of these species in the Marquesas extends the eastern boundary of their biogeographic range. The brachiopods from the Marquesas show very low diversity when compared with the fauna from the western Pacific, as well as with that from the Hawaiian Islands. This decrease in number of species in the Pacific from west to east is also observed in other benthic invertebrate groups.
\end{abstract}

Although Recent brachiopods have been investigated intensively in the Pacific Ocean, especially around Japan, Australia, and New Zealand, they are rather poorly known from off the archipelago islands. The Pacific islands region recently has been studied by several French oceanographic expeditions on the R.V. Alis. This paper deals with the brachiopods that were collected during the Musorstom 9 Expedition to the Marquesas Islands from 18 August to 11 September 1997 (Richer de Forges et al. 1999). The Marquesas are a 350-km-long chain of high volcanic islands in the South Central Pacific, constituting the northernmost part of French Polynesia. They are one of the most isolated archipelagoes, with high endemism in many groups (Springer 1982, Randall 2001).

The brachiopods examined here came from 12 stations on the slopes of Eiao, Nuku Hiva, Ua Pou, and Fatu Hiva Islands (Figure 1). This is the first record of brachiopods from the Marquesas Islands. The diversity of

\footnotetext{
${ }^{1}$ Manuscript accepted 26 October 2005.

${ }^{2}$ Institute of Paleobiology, Polish Academy of Sciences, ul. Twarda 51/55, 00-818 Warszawa, Poland (e-mail: bitner@twarda.pan.pl).
}

Pacific Science (2006), vol. 60, no. 3:417-424

(C) 2006 by University of Hawai'i Press

All rights reserved brachiopods is very low, and they are represented by only two species: Eucalathis cf. murrayi (Davidson, 1878) and Frenulina sanguinolenta (Gmelin, 1791).

The investigated specimens are deposited in the Muséum national d'Histoire naturelle in Paris, France (MNHN-BRA). The location, depth, and species identified at the stations are given in the Appendix.

SYSTEMATIC ACCOUNT

Superfamily Cancellothyridoidea Thomson, 1926

Family Chlidonophoridae Muir-Wood, 1959

Subfamily Eucalathinae Muir-Wood, 1965

Genus Eucalathis Fischer \& Oehlert, 1890

TYPE SPECIES: Terebratulina murrayi Davidson, 1878, by original designation of Fischer and Oehlert (1890:72).

Eucalathis cf. murrayi (Davidson, 1878)

Figure $2 A-C$

cf. Terebratulina murrayi Davidson, 1878:437; Davidson, 1880:39, pl. 2, fig. 1; Davidson, 1886:39, pl. 6, figs. 15-17.

cf. Eucalathis murrayi: Muir-Wood, 1959:296, pl. 4, figs. 2, 3; pl. 5, figs. 9, 10; Foster, 1974:83, pl. 7, figs. 10-12; Zezina, 1985:134; Zezina, 1987:556-557. 


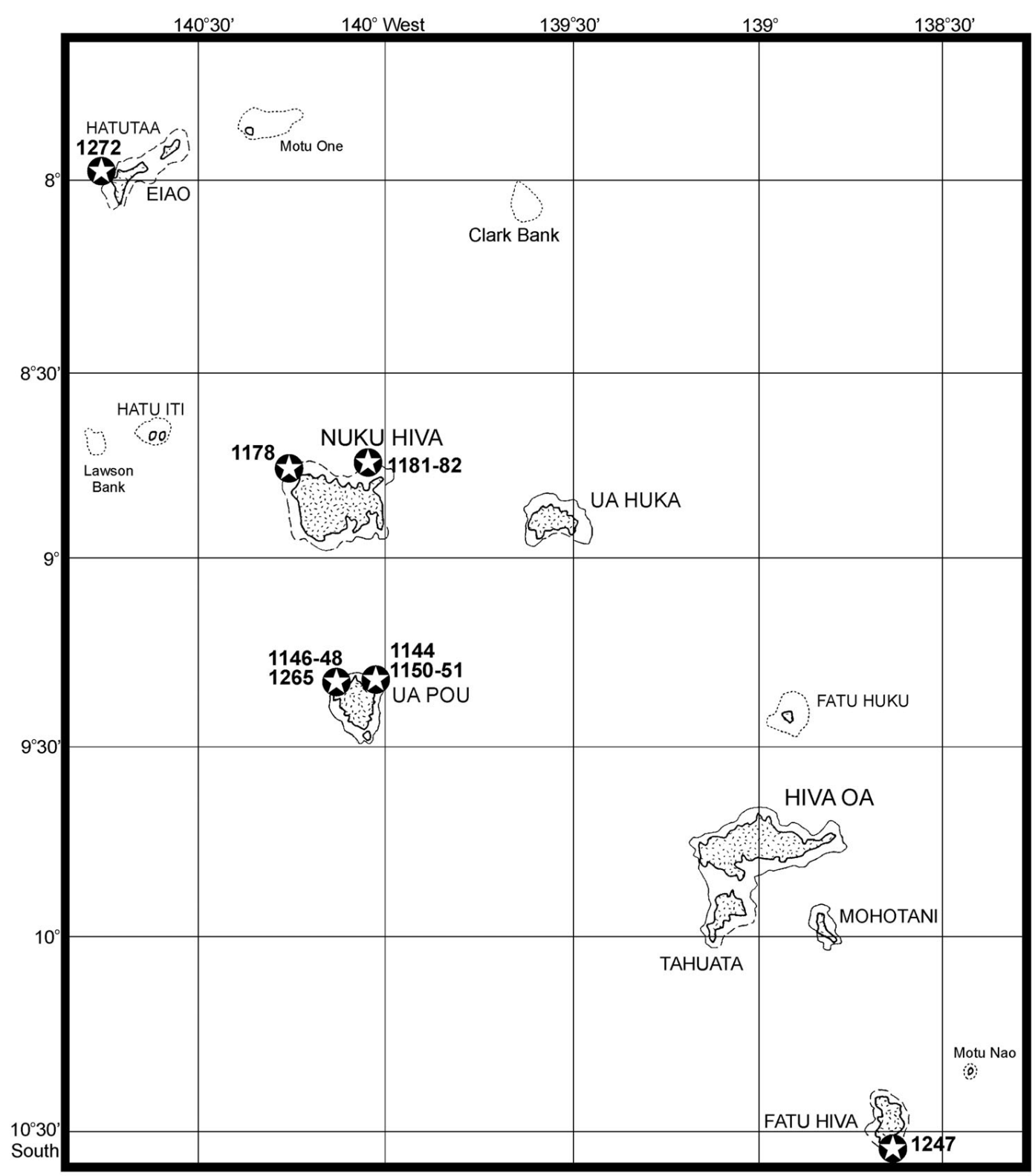

Figure 1. Map of the Marquesas Islands, French Polynesia; stations with brachiopods are indicated by a star (simplified after Richer de Forges et al. 1999).

MATERIAL EXAMINed: Marquesas: Musorstom 9, Eiao Island, station CP 1272: one complete specimen.

DEPTH RANGE: 660-680 $\mathrm{m}$.
Dimensions: Length $2.8 \mathrm{~mm}$, width 2.8 mm, thickness $1.7 \mathrm{~mm}$.

DESCRIPTION: The shell is small, broadly triangular, as long as wide, biconvex with ven- 


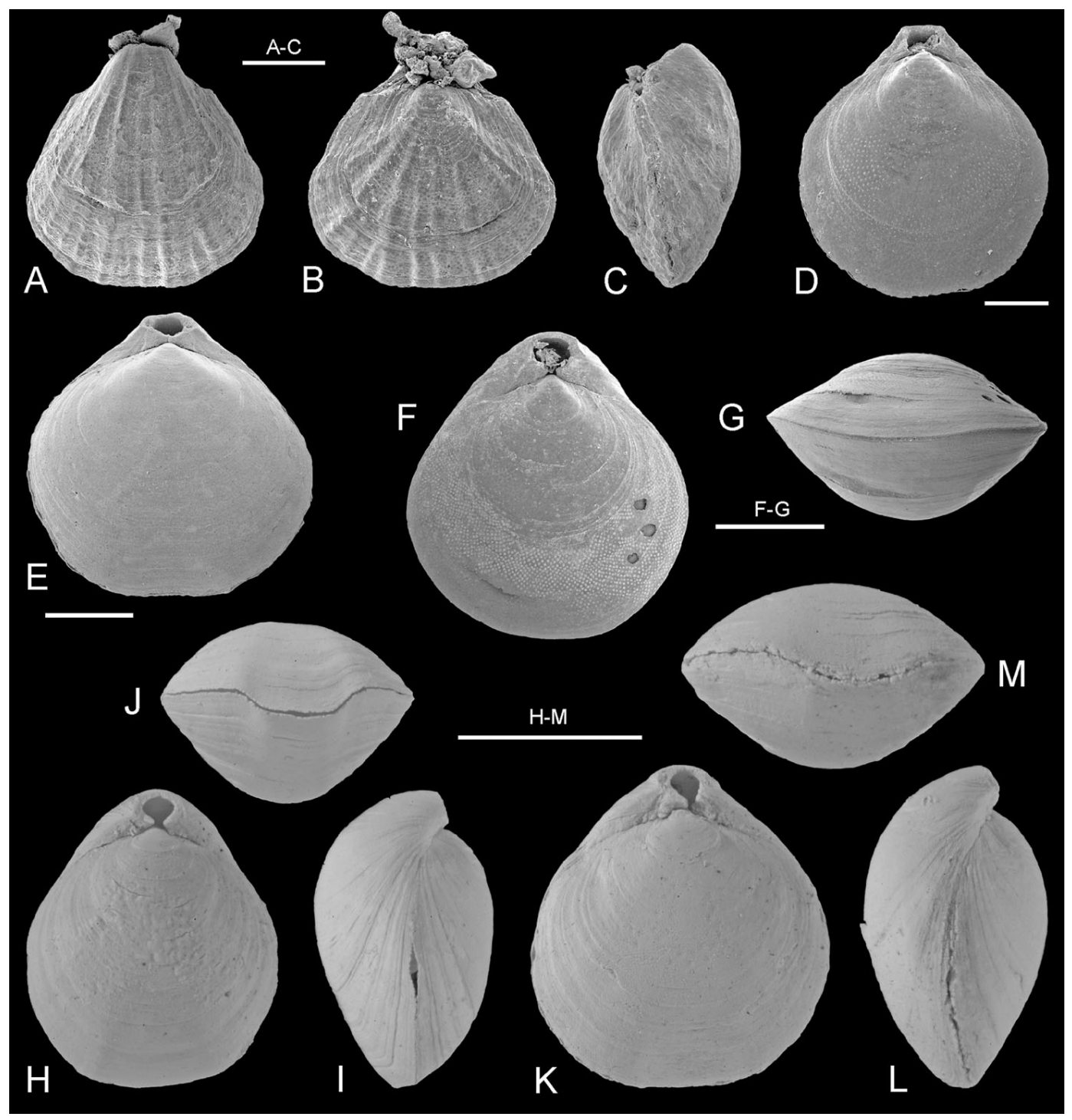

FIgUre 2. A-C, Eucalathis cf. murrayi (Davidson): SEMs of ventral $(A)$, dorsal $(B)$, and lateral $(C)$ views of complete specimen (мNHN-BRA-3029), Marquesas, Eiao Island, CP 1272, 660-680 m. D-M, Frenulina sanguinolenta (Gmelin), Marquesas: D, SEM of dorsal view of complete young specimen (MNHN-BRA-3030), Nuku Hiva Island, CP 1178, 74$75 \mathrm{~m}$; E, SEM of dorsal view of complete specimen (MNHN-BRA-3031), Fatu Hiva Island, DR 1247, 1150-1250 m; $F-G$, SEMs of dorsal and anterior views of complete specimen (mNHN-BRA-3032), Nuku Hiva Island, CP 1178, 74$75 \mathrm{~m} ; H-M$, dorsal $(H, K)$, lateral $(I, L)$, and anterior $(\mathcal{F}, M)$ views of complete specimens, Ua Pou Island; $H-\mathcal{F}$, CP 1265, 90-92 m, мNHN-вRA-3033; $K-M$, DW 1146, 200 m, MNHN-Bra-3034. Scale bars: $A-D, 1 \mathrm{~mm} ; E-G, 2 \mathrm{~mm}$; $H-M, 0.5 \mathrm{~cm}$. 
tral valve more convex. The surface is covered with about 10 primary ribs that increase to $17-18$ by bifurcation. The beak is short, suberect. The foramen is large, mesothyrid, bordered by two minute deltidial plates. The hinge line is slightly curved and wide. The anterior commissure is rectimarginate. The internal characters are unknown.

REMARKS: The investigated material is very limited; nevertheless externally it displays characters typical of the genus Eucalathis. This genus, widely distributed in modern waters, is represented by several species in the Indo-Pacific region, namely Eucalathis murrayi, E. rugosa, E. fasciculata, E. macrorbynchus, E. costellata, E. magna, E. rotundata (Davidson 1886, Cooper 1973a,b, 1981, Foster 1974, 1989, Zezina 1985, 1987, Hiller 1986, 1994, d'Hondt 1987, Dawson 1991, Laurin 1997). The studied specimen shows close affinities to E. murrayi, but it is much smaller and has less-pronounced ribs with wider spaces between them. Having only one specimen makes detailed taxonomic studies difficult, not allowing investigation of intraspecific variability. Eucalathis murrayi was originally described from off the Kermadec Islands (Davidson 1880, 1886, Dawson 1991). Later this species was also reported from the Indian Ocean (Zezina 1987).

The investigated specimen displays ornamentation similar to that of specimens of $E$. macrorhynchus Foster, 1974, from the PacificAntarctic Ridge. The latter species differs, however, in having a higher beak and narrow, elongated deltidial plates (Foster 1974). The specimens assigned later to the same species by Foster (1989) differ from the material discussed here in being much larger and having more numerous distinct ribs.

In size, outline, and ornamentation the specimen collected from off the Marquesas Islands is also similar to Eucalathis fasciculata Cooper from south of Madagascar (Cooper 1973b, Hiller 1986). The latter species has, however, a higher beak and narrower hinge line.

Gaspard (2003) determined some specimens from off Portugal as Eucalathis aff. murrayi, but those specimens differ strongly from the investigated specimen in having a more rounded outline, higher beak, and wider hinge line.

$$
\begin{gathered}
\text { Superfamily Laqueoidea Thomson, } 1927 \\
\text { Family Frenulinidae Hatai, } 1938 \\
\text { Genus Frenulina Dall, } 1895
\end{gathered}
$$

TyPe SPECIEs: Anomia sanguinolenta Gmelin, 1791, by original designation of Dall (1895:724).

Frenulina sanguinolenta (Gmelin, 1791)

Figures $2 D-M, 3 A-F$

Anomia sanguinolenta Gmelin, 1791:3347.

Megerlia sanguinea Davidson, 1887:108-111, pl. 20, figs. 1-8.

Frenulina sanguinolenta: Dall, 1895:724; Dall, 1920:336-337; Hatai, 1940:327-329, pl. 4, figs. 42, 44-47, 49, 50, 52-54; Cooper, $1973 b: 21-22$, pl. 6, figs. $1-3$; pl. 8, figs. 12-16; Zezina, 1985:168; d'Hondt, 1987:38; Emig, 1987:169, pl. 2.V.1, figs. $b, c$; Laurin, 1997:450-451, fig. 47H-7.

material examined: Marquesas: $\mathrm{Mu}-$ sorstom 9, Ua Pou Island, station DW 1144: three juvenile complete specimens; station DW 1146: one complete specimen; station DW 1147: one complete specimen; station DW 1148: one juvenile complete specimen; station DR 1150: one complete specimen; station DR 1151: two complete specimens (empty shells); station CP 1265: four complete specimens. Nuku Hiva Island, station CP 1178: 10 complete specimens; station DR 1181: 13 complete specimens; station DR 1182: one complete specimen. Fatu Hiva Island, station DR 1247: one complete specimen, one ventral valve.

DEPTH RANGE: $70-1,250 \mathrm{~m}$.

Dimensions: Given in Table 1.

REMARKs: Frenulina sanguinolenta is widely distributed in the western Pacific Ocean, from Japan to Australia, New Caledonia, and Fiji (Davidson 1887, Thomson 1918, 1927, Jackson and Stiasny 1937, Hatai 1940, Richardson 1979, Zezina 1985, d'Hondt 1987, Laurin 1997, Bitner 2006). This species is also reported from Hawai' $i$, in the North Central 


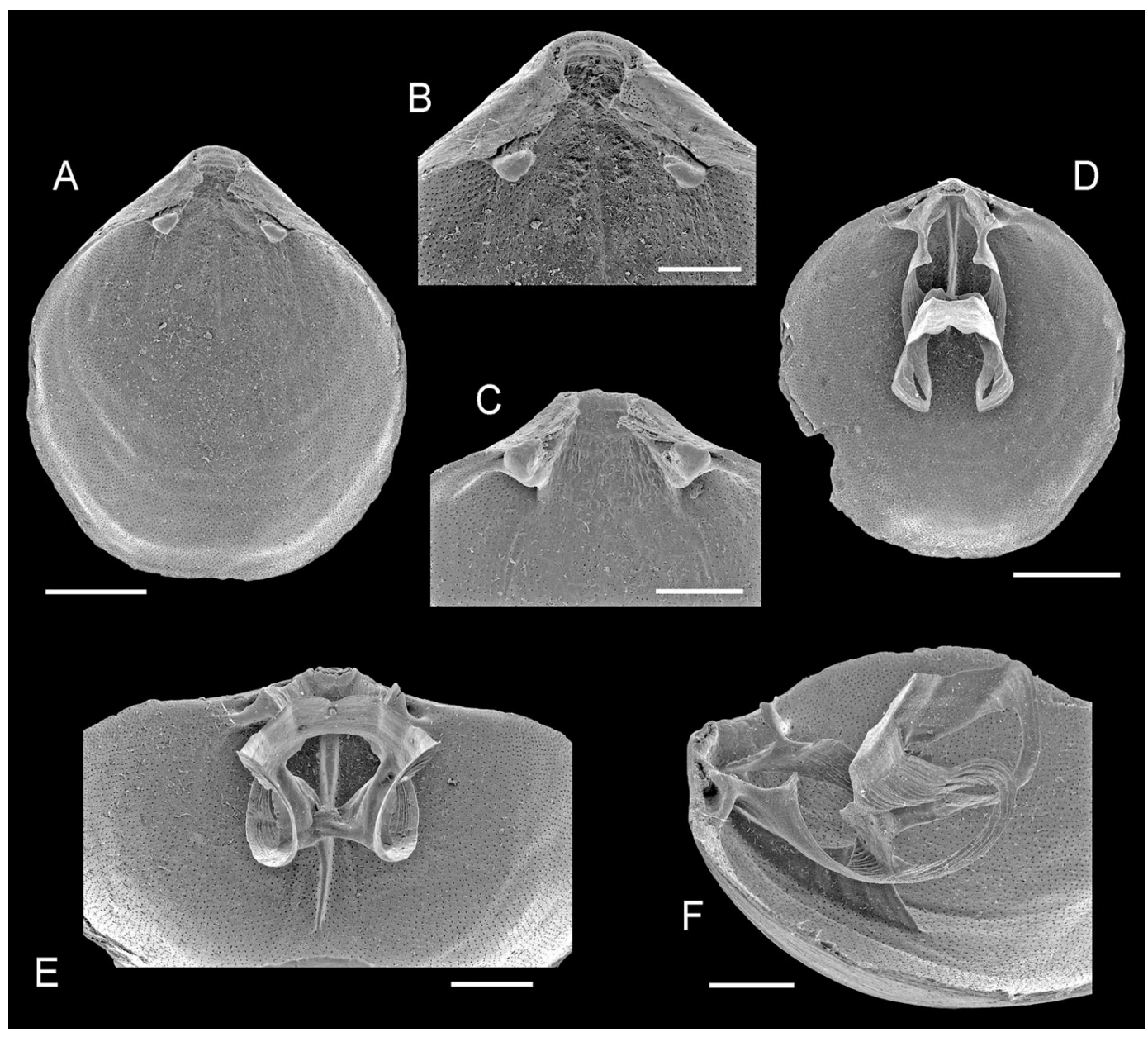

Figure 3. Frenulina sanguinolenta (Gmelin), Marquesas, Ua Pou Island, DR 1151, 70-77 m (мNhN-bra-3035): $A-C$, ventral valve interior $(A)$, enlargement of posterior part $(B)$, and tilted view $(C)$ to show dental plates; $D-F$, dorsal valve interior $(D)$, enlargements of tilted $(E)$ and side $(F)$ views to show brachial loop. All SEM. Scale bars: $A, D$, $2 \mathrm{~mm} ; B, C, E, F, 1 \mathrm{~mm}$.

TABLE 1

Dimensions (in mm) of Specimens of Frenulina sanguinolenta

\begin{tabular}{lccc}
\hline \hline Station No. & Length & Width & Thickness \\
\hline CP 1265 & 9.1 & 7.2 & 5.6 \\
CP 1265 & 8.1 & 6.9 & 4.9 \\
DW 1146 & 8.8 & 8.1 & 5.1 \\
DW 1147 & 6.1 & 5.5 & 2.7 \\
CP 1178 & 5.0 & 4.3 & 2.5 \\
CP 1178 & 3.9 & 3.4 & 1.6 \\
\hline
\end{tabular}

Pacific (Dall 1895, 1920, Emig 1987). It is easily distinguishable by its characteristic red color pattern. The shell is small (maximum observed length $9.1 \mathrm{~mm}$ ), biconvex, and quite variable in outline, from circular, subpentagonal, to elongately oval. The shell surface is smooth with numerous growth lines visible. The beak is suberect with weak beak ridges. The foramen is large, mesothyrid to submesothyrid. The triangular deltidial plates may be disjunct, nearly conjunct, to fully conjunct. 
The anterior commissure is rectimarginate in immature individuals to weakly sulcate in adults. The ventral valve interior has a pedicle collar closely applied to the valve floor and teeth supported by dental plates. The cardinalia has a prominent cardinal process and long inner socket ridges. The brachial skeleton forms a long loop with a wide transverse band, attached to a medium septum (Figure $3 D-F)$.

In the Marquesas region this species was collected at depths of 70-480 m; however, two empty shells were dredged on the steep slopes at depths of 1,150-1,250 $\mathrm{m}$ and were most probably transported from shallower water. The bathymetric range for this species given by Zezina (1985) is 24 to $545 \mathrm{~m}$. In the New Caledonia region $F$. sanguinolenta was collected at depths of $20-525 \mathrm{~m}$ (Laurin 1997).

\section{DISCUSSION}

The two species of brachiopods collected in the region of the Marquesas Islands during the French Musorstom 9 Expedition, Eucalathis cf. murrayi and Frenulina sanguinolenta, represent the first record of brachiopods from that region. Both species occur in the southwestern Pacific (d'Hondt 1987, Dawson 1991, Laurin 1997, Bitner 2006), and F. sanguinolenta is also reported from the Hawaiian Islands (Dall 1895, 1920, Emig 1987). Thus the presence of these species in the Marquesas extends the eastern boundary of their biogeographic range. The biodiversity of the brachiopod fauna is much lower than that around the Fiji Islands (Bitner 2005, 2006) and New Caledonia (Laurin 1997), where 17 and 26 species have been recognized, respectively. The brachiopod fauna from Hawai'i is also more diversified than that from the Marquesas and consists of seven species (Dall 1895, 1920, Emig 1987). The Marquesas Islands are one of the most isolated archipelagos in the central Pacific, and the benthic fauna is remarkably poor in all groups of organisms (Springer 1982, Richer de Forges et al. 1999), probably because there are no seamounts that could have been used as dispersal steps between the Marquesas and other islands; the pattern of currents around the Marquesas indicates that transport today is generally away from the archipelago (Springer 1982).

In the Pacific, a decrease in species diversity from west to east can be observed in all groups of invertebrates, including articulate brachiopods, and species diversity in the midocean region is usually poorer than that near continental parts of the bathyal zone (Zezina 1997, 2001).

\section{ACKNOWLEDGMENTS}

My sincere thanks are due to B. Richer de Forges (Institut de la Recherche pour le Développement, Nouméa) and A. Crosnier (Muséum national d'Histoire naturelle, Paris) for the opportunity to study the material. L. G. Eldredge (Bishop Museum, Honolulu) and an anonymous reviewer are thanked for helpful comments that improved the manuscript. I am grateful to D. E. Lee (University of Otago, Dunedin) and D. I. MacKinnon (University of Canterbury, Christchurch) for making available their unpublished data on brachiopod systematics. The photographs were taken by Ms. G. Dziewińska (Institute of Paleobiology, Warszawa). The SEM micrographs were taken in the SEM laboratory of the Institute of Paleobiology (Warszawa) using a scanning microscope (Philips XL-20).

\section{Literature Cited}

Bitner, M. A. 2005. Recent brachiopods from the Fiji and Marquesas Islands, southern Pacific, collected during the French cruises Musorstom 9, 10 and Bordau 1. Pages 3536 in D. A. T. Harper, S. L. Long, and M. McCorry, eds. 5th International Brachiopod Congress, Copenhagen, 2005 (abstract).

2006. Recent brachiopods from the Fiji and Wallis and Futuna Islands, Southwest Pacific. In J. L. Justine and B. Richer de Forges, eds. Tropical deep sea benthos, vol. 24. Mém. Mus. Natl. Hist. Nat. 193 (in press). 
Cooper, G. A. 1973a. Fossil and Recent Cancellothyridacea (Brachiopoda). Sci. Rep. Tohoku Univ. 2nd Ser. (Geol.), Spec. Vol. (Hatai Memorial Volume) 6:371-390. . 1973b. New Brachiopoda from the Indian Ocean. Smithson. Contrib. Paleobiol. 16:1-45. 1981. Brachiopods from the southern Indian Ocean (Recent). Smithson. Contrib. Paleobiol. 43:1-93.

Dall, W. H. 1895. Report on the Mollusca and Brachiopoda dredged in deep water, chiefly near the Hawaiian Islands, with illustrations of hitherto unfigured species from Northwest America. Proc. U.S. Natl. Mus. 17:675-733.

- 1920. Annotated list of the Recent Brachiopoda in the collection of the United States National Museum, with description of thirty-three new forms. Proc. U.S. Natl. Mus. 57:261-377.

Davidson, T. 1878. Extract from a report to Professor Sir Wyville Thomson F.R.S., director of the civilian scientific staff, on the Brachiopoda dredged by H.M.S. Challenger. Proc. R. Soc. Lond. 27:428-439.

. 1880. Report on the Brachiopoda dredged by H.M.S. Challenger during the years 1873-1876. Rep. Sci. Res. Voyage of H.M.S. Challenger (Zool.) 1:1-67.

- 1886-1888. A monograph of recent Brachiopoda. Parts I-III. Trans. Linn. Soc. Lond., 2nd ser., Zool. 4:1-248.

Dawson, E. W. 1991. The systematics and biogeography of the living Brachiopoda of New Zealand. Pages 431-437 in D. I. MacKinnon, D. E. Lee, and J. D. Campbell, eds. Brachiopods through time. Proc. 2nd Int. Brachiopod Congress, Dunedin, New Zealand, 1990. Balkema, Rotterdam.

d'Hondt, J.-L. 1987. Observations sur les Brachiopodes actuels de NouvelleCalédonie et d'autres localités de l'IndoPacifique. Bull. Mus. Natl. Hist. Nat. Sect. A Zool. Biol. Ecol. Anim., 4 sér. 9:33-46.

Emig, C. C. 1987. Phylum Brachiopoda. In D. M. Devany and L. G. Eldredge, eds. Reef and shore fauna of Hawaii. Section 2: Platyhelminthes through Phoronida and Section 3: Sipuncula through Anne- lida. Bernice P. Bishop Mus. Spec. Publ. 64:167-170.

Fischer, P., and D. P. Oehlert. 1890. Diagnoses de nouveaux brachiopodes. J. Conchyliol., ser. 3, 38:70-74.

Foster, M. W. 1974. Recent Antarctic and subantarctic brachiopods. Antarct. Res. Ser. 21:1-189. 1989. Brachiopods from the extreme South Pacific and adjacent waters. J. Paleontol. 63:268-301.

Gaspard, D. 2003. Recent brachiopods collected during the "Seamount 1" Cruise off Portugal and the Ibero-Moroccan Gulf (northeastern Atlantic) in 1987. Geobios 36:285-304.

Gmelin, J. F. 1791. Pages 3021-3909 in Caroli a Linné, Systema naturae. Tom I. Pars VI. 13 ed. Beer, Lipsiae.

Hatai, K. M. 1940. The Cenozoic Brachiopoda from Japan. Sci. Rep. Tohoku Imp. Univ., 2nd Ser. (Geol.) 20:1-413.

Hiller, N. 1986. The South African Museum's Meiring Naude cruises. Part 16. Brachiopoda from the 1975-1979 cruises. Ann. S. Afr. Mus. 97:97-140.

- 1994. The environment, biogeography, and origin of the southern African Recent brachiopod fauna. J. Paleontol. 68:776-786.

Jackson, J. W., and G. Stiasny. 1937. The Brachiopoda of the Siboga Expedition. Siboga-Expeditie 27:1-20.

Laurin, B. 1997. Brachiopodes récoltés dans les eaux de la Nouvelle Calédonie et des îles Loyauté, Matthew et Chesterfield. In A. Crosnier, ed. Résultats des Campagnes Musorstom, vol. 18. Mém. Mus. Natl. Hist. Nat. 176:411-471.

Muir-Wood, H. 1959. Report on the Brachiopoda of the John Murray Expedition. Sci. Rep. John Murray Exp. 1933-1934 10:283-317.

Randall, J. E. 2001. Four new cardinalfishes (Perciformes: Apogonidae) from the Marquesas Islands. Pac. Sci. 55:47-64.

Richardson, J. 1979. Pedicle structure of articulate brachiopods. J. R. Soc. N. Z. 9:414-436.

Richer de Forges, B., J. Poupin, and P. Laboute. 1999. La campagne Musorstom 9 
dans l'archipel des îles Marquises (Polynésie française). Compte rendu et liste des stations. In A. Crosnier, ed. Résultats des Campagnes Musorstom, vol. 20. Mém. Mus. Natl. Hist. Nat. 180:9-29.

Springer, V. G. 1982. Pacific Plate biogeography, with special reference to shorefishes. Smithson. Contrib. Zool. 367:1182.

Thomson, J. A. 1918. Brachiopoda. In Australasian Antarctic Expedition 1911-1914. Sci. Rep., ser. C, 4 (3): 1-76.

. 1927. Brachiopod morphology and genera (Recent and Tertiary). N. Z. Board Sci. Art, Manual 7.

Zezina, O. N. 1985. Sovremennye brakhiopody i problemy batialnoj zony okeana [Recent brachiopods and problems of the bathyal zone of the ocean]. Nauka, Moskva. [in Russian.]

1987. Brachiopods collected by Benthedi-Cruise in the Mozambique Channel. Bull. Mus. Natl. Hist. Nat., Sect. A Zool. Biol. Ecol. Anim., 4 sér. 9:551563.

. 1997. Biogeography of the bathyal zone. In A. V. Gebruk, E. C. Southward, and P. A. Tyler, eds. The biogeography of the oceans. Adv. Mar. Biol. 32:389426.

. 2001. Global surface-water circulation and the main features of brachiopod biogeography. In C. H. C. Brunton, L. R. M. Cocks, and S. L. Long, eds. Brachiopods past and present. Syst. Assoc. Spec. Vol. 63:102-107.

Appendix

Marquesas Islands Station List

\begin{tabular}{llll}
\hline \hline Station & \multicolumn{1}{c}{ Location } & \multicolumn{1}{c}{ Depth } & \multicolumn{1}{c}{ Species } \\
\hline Ua Pou Island & & & \\
DW 1144 & $9^{\circ} 19.3^{\prime} \mathrm{S}, 140^{\circ} 03.8^{\prime} \mathrm{W}$ & $85-95 \mathrm{~m}$ & Frenulina sanguinolenta \\
DW 1146 & $9^{\circ} 18.8^{\prime} \mathrm{S}, 140^{\circ} 06.2^{\prime} \mathrm{W}$ & $200 \mathrm{~m}$ & Frenulina sanguinolenta \\
DW 1147 & $9^{\circ} 191^{\prime} \mathrm{S}, 140^{\circ} 06.5^{\prime} \mathrm{W}$ & $205-302 \mathrm{~m}$ & Frenulina sanguinolenta \\
DW 1148 & $9^{\circ} 18.9^{\prime} \mathrm{S}, 140^{\circ} 063^{\prime} \mathrm{W}$ & $300 \mathrm{~m}$ & Frenulina sanguinolenta \\
DR 1150 & $9^{\circ} 18.2^{\prime} \mathrm{S}, 140^{\circ} 04.8^{\prime} \mathrm{W}$ & $450-480 \mathrm{~m}$ & Frenulina sanguinolenta \\
DR 1151 & $9^{\circ} 19.4^{\prime} \mathrm{S}, 140^{\circ} 03.7^{\prime} \mathrm{W}$ & $70-77 \mathrm{~m}$ & Frenulina sanguinolenta \\
CP 1265 & $9^{\circ} 20.4^{\prime} \mathrm{S}, 140^{\circ} 07.3^{\prime} \mathrm{W}$ & $90-92 \mathrm{~m}$ & Frenulina sanguinolenta \\
Nuku Hiva Island & $8^{\circ} 46.1^{\prime} \mathrm{S}, 140^{\circ} 14.5^{\prime} \mathrm{W}$ & $74-75 \mathrm{~m}$ & Frenulina sanguinolenta \\
CP 1178 & $8^{\circ} 45.5^{\prime} \mathrm{S}, 140^{\circ} 03.2^{\prime} \mathrm{W}$ & $102-130 \mathrm{~m}$ & Frenulina sanguinolenta \\
DR 1181 & $8^{\circ} 45.6^{\prime} \mathrm{S}, 140^{\circ} 03.9^{\prime} \mathrm{W}$ & $90-120 \mathrm{~m}$ & Frenulina sanguinolenta \\
DR 1182 & $10^{\circ} 34.0^{\prime} \mathrm{S}, 138^{\circ} 41.6^{\prime} \mathrm{W}$ & $1,150-1,250 \mathrm{~m}$ & Frenulina sanguinolenta \\
Fatu Hiva Island & & & \\
DR 1247 & $7^{\circ} 55.5^{\prime} \mathrm{S}, 140^{\circ} 43.6^{\prime} \mathrm{W}$ & $660-680 \mathrm{~m}$ & Eucalathis cf. murrayi \\
Eiao Island & & & \\
CP 1272 & &
\end{tabular}

